ЭКОНОМИЧЕСКАЯ, СОЦИАЛЬНАЯ И ПОЛИТИЧЕСКАЯ ГЕОГРАФИЯ 


\title{
БЕРЕГОВЫЕ ВОДОПАДЫ КУРИЛЬСКИХ ОСТРОВОВ КАК ОБЬЕКТ ТУРИЗМА
}

\author{
Васина М.B. \\ Дальневосточный федеральный университет, Владивосток \\ mashishya@mail.ru
}

Аннотация. Водопады Курильских островов представляют большой интерес с точки зрения туризма, и особенно все большей популярностью пользуется туризм береговых зон. Береговая линия Курил весьма изрезана, в ее пределах встречается множество интересных объектов, в том числе и водопады. Курилы можно справедливо назвать краем водопадов. На этих островах их более 300 , и каждый год открываются все новые. Почти на каждом острове Курильской гряды можно найти «летящую воду». Большой вклад в изучение водопадов Сахалинской области внес ученый и путешественник Андрей Клитин. Он обошел пешком крупнейшие острова Курильской гряды - Кунашир, Итуруп, Уруп, Симушир, Онекотан и Парамушир, открыл и нанес на карту множество новых водопадов, составил точное описание своих маршрутов. Его описания до сих пор берутся за основу путешественниками. К этим водопадам можно добавить также водопады, самостоятельно обнаруженные автором, и пока не обозначенные на карте. С помощью электронного ресурса Google Earth автором обнаружены новые водопады на о-вах Шиашкотан, Расшуа, тихоокеанской стороне о-вов Симушир и Онекотан. Эти «открытия», безусловно, требуют полевого подтверждения. В статье предлагается разработка нескольких «водопадных» береговых маршрутов, продолжительностью 1-2 дня, по островам Кунашир, Итуруп, Уруп, Онекотан и Парамушир.

Ключевые слова: Курильские острова, водопады, береговые водопады, туризм, маршруты по островам.

\section{SHORE WATERFALLS OF THE KURIL ISLANDS AS AN OBJECT OF TOURISM}

\author{
Vasina M.V. \\ Far Eastern Federal University, Vladivostok
}

Annotation. The waterfalls of the Kuril Islands are of great interest from the point of view of tourism, especially the increasing popularity of tourism on coastal zones. The coastline of the Kuril Islands is highly indented. It is found a lot of interesting objects, including waterfalls. The Kuril Islands rightly can be called the land of waterfalls. On these Islands more than 300, and every year discover the new waterfalls. Almost every island of the Kuril ridge it is possible to find waterfalls. A great contribution to the study of waterfalls Sakhalin region has made scientist and traveler Andrey Klitin. He went to the largest of 
the Kuril Islands - Kunashir, Iturup, Urup, Simushir, Onekotan and Paramushir, discovered and mapped many new waterfalls, was an accurate description of himself routes. His descriptions still are the foundation by the travelers. To these waterfalls, you can also add waterfalls, independently discovered, and it is not marked on the map. Using the e-resource Google Earth were found by the author a new waterfalls on the Islands of Shiashkotan, Rasshua, Pacific side of the Islands Simushir and Onekotan. These "discoveries", of course, require experimental confirmation. The article proposes the elaboration of several "waterfall" coastal trails, lasting 1-2 days, to the Islands of Iturup, Kunashir, Urup, Paramushir and Onekotan.

Key words: Kuril Islands, waterfalls, coast waterfalls, tourism, hiking trails on islands.

Водопады всегда привлекали к себе внимание человека. В современном мире водопады пользуются все большей популярностью у туристов, как средство избавления от стрессов и суеты городской жизни. Особенно если эти водопады находятся в буквальном смысле «на краю земли». Пребывание близ водопадов приносит не только эстетическое удовольствие, но и имеет целебный эффект: падающая с высоты вода образует водяную пыль, в которой под воздействием солнечных лучей образуются отрицательно заряженные ионы. Такая пыль, насыщенная фитонцидами растений, которых близ водопадов всегда в избытке, оказывает очень большой положительный эффект на организм. Водопад удивляет человека не только падением огромной массы воды с большой высоты, но и звуковыми эффектами. У некоторых водопадов за счёт отражения звука от высоких скал создаются благоприятные условия для резонанса воздушной среды между скалами, в результате шум водопада кажется громче [7].

Водопад возникает в месте перегиба продольного профиля водотока, где вода находится в свободном падении или стекает по крутому уступу. Согласно Г. Т. Арсееву, «Любой водопад - сложное явление, арена и результат борьбы и взаимодействия Воды, Камня и Атмосферы. Здесь протекают сложнейшие процессы гидроаэроионизации, естественной флотации, непрестанной, не прекращающейся ни на секунду, эрозии. Действующие водопады, по своей сути - природные «вечные двигатели». Также он предлагает считать водопадом низвержение воды с уступа под углом более 45 градусов, а падение воды под углом менее 45 градусов - водоскатом, падуном (стремниной, быстриной). Водопад менее 1 м высотой следует относить к порогам (сливам).

Высота падения и ширина потока - две важнейшие характеристики любого водопада, но поскольку, согласно определению, основу его 
составляет «падение воды с уступа» той или иной высоты, главный критерий при оценке любого водопада - его высота. Также одной из важнейших характеристик является водоносность водопада (расход воды через гребень) [1].

К общему понятию водопадов относятся и сезонные, которые появляются на несколько месяцев, дней, и даже часов в году. На Шантарах, а также в Приморье и на Сахалине отмечены сезонные водопады, которые при длительном отсутствии атмосферных осадков пересыхают, но превращаются в бурные потоки во время дождей [1]. Есть такие и на Курилах. Их существование зависит от температуры воздуха, количества атмосферных осадков в данный сезон года, характера поверхности, по которой проложено русло. Дело в том, что многие потоки берут свое начало с вершин вулканов, где накапливаются атмосферные осадки в виде снега. Поверхность вулкана может быть сложена пористыми породами (туфы, лавобрекчии, пемза) и при дожде или таянии снега влага не задерживается долго на поверхности, она впитывается. В этом случае только при обильных осадках и наличии уступа в русле возможно существование временного водопада.

Климатические условия Курильских островов предполагают достаточно густую и полноводную речную сеть. Благодаря этому в горах образуется огромное количество речек и ручьев. Питают их обильные атмосферные осадки, на крупных островах в этом участвуют и грунтовые воды. Например, с северо-восточной стороны мыса Рикорда на юге острова Итуруп, два 15-метровых водопада бьют прямо из отверстия в скале, по-видимому, из одного водоносного горизонта грунтовых вод [3]. В конце мая таяние снега принимает более интенсивный характер, к тому же начинается сезон муссонов. Высокий уровень воды сохраняется вплоть до конца августа. Выпадение снега начинается уже в октябре, при этом снежный покров быстро устанавливается и достигает своей максимальной мощности. Замерзание рек и ручьев начинается в декабре и держится до таяния снега весной. Водопады в холодное время года представляют собой ледопады (в том случае, если вода в реке не подогревается расположенным вблизи действующим вулканом).

Береговые водопады являются характерной особенностью многих дальневосточных островов: их можно встретить на Шантарских, Командорских островах, на Сахалине и Курильских островах. 
Большинство береговых водопадов Курильских островов принадлежит к абразионному типу - когда эрозия не успевает «пропиливать» береговые уступы, возникают водопады на клифах - висячие устья. Их высота зависит от литологического состава пород, слагающих берега, и темпов абразии.

Встречаются и водопады абразионно-тектонического типа, когда водопадный уступ образуется при пересечении разломом речного русла или землетрясении, когда происходит подвижка отдельных блоков. В условиях побережья работу по формированию русла продолжает абразия. К подобным можно отнести водопады на юго-западном побережье Парамушира между мысом Капустный и рекой Стрела, возникновение которых связывают с неотектоническим подъемом этого участка берега [3].

Береговые водопады очень красивы, но часто неприступны с берега - их воды срываются с высоких уступов прямо в море. Это свойство иногда используется в практических целях - для заправки судов чистой пресной водой (Шантарские, Курильские острова). На Курильских островах известны несколько таких источников:

- Безымянный 20-метровый водопад на острове Кунашир в центральной его части, у мыса Подпорный, на тихоокеанской стороне;

- На полуострове Чирип (остров Итуруп) абразионный «Заправочный» водопад в бухте Консервной, высотой 8 метров. Высота водопада, сила потока и глубина возле берега здесь таковы, что вода самотеком направляется по шлангам в питьевые танки судов [1];

- На острове Симушир, на охотоморской стороне, в бухте Китобойная, 17-метровый водопад, который можно увидеть только с моря.

Береговые водопады могут служить и ориентиром, точкой привязки к объекту. Многие высокие островные мысы украшают водопады. Например, именем Илья Муромец на острове Итуруп называется один из самых высоких водопадов Дальнего Востока (141 м) и мыс на самом севере острова. На острове Кетой, на самом северном его мысе Сторожева, есть водопад Каскад.

Общее число водопадов на Курильских островах Кунашир, Итуруп, Уруп, Симушир, Онекотан, Парамушир, изведанных и нанесенных на карту А. Клитиным, составляет 389 [3]. Многие острова он не успел обойти полностью, исследовав, например, только охотоморскую сторону Симушира, часть охотоморской стороны Онекотана. Распределение прибрежных и внутриостровных водопадов в 
среднем составляет $56 \%$ на $43 \%$ соответственно, но разнится по островам [3].

На сегодняшний день, благодаря электронным ресурсам программы Google Earth, можно с некоторой смелостью виртуально «открыть» водопады еще неизведанных в этом плане Курильских берегов. Таким образом, попробуем найти и приблизительно определить высоту водопадов на тихоокеанской стороне островов Онекотан, Симушир и Шиашкотан по периметру. Также известны водопады на берегах островов Кетой, Расшуа (табл.).

Т а б ли ц а

Классификация береговых водопадов по высоте

\begin{tabular}{|c|c|c|c|c|c|c|c|c|c|}
\hline Остров & & & & & & & & & \\
\hline Высота, м & 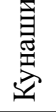 & 吝 & 胥 & 禀 & 敢 & 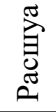 & $\begin{array}{l}\text { 息 } \\
\text { 舁 }\end{array}$ & 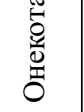 & 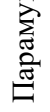 \\
\hline $0-10$ & 27 & 31 & 19 & 3 & 0 & 0 & 2 & 5 & 30 \\
\hline $11-50$ & 15 & 48 & 22 & 9 & 1 & 2 & 6 & 5 & 20 \\
\hline $51-100$ & 0 & 3 & 2 & 4 & 0 & 7 & 0 & 0 & 0 \\
\hline более100 & 0 & 1 & 0 & 2 & 0 & 2 & 0 & 0 & 0 \\
\hline береговые & 25 & 69 & 40 & 18 & 1 & 0 & 8 & 10 & 44 \\
\hline $\begin{array}{l}\text { на расстоянии. до } \\
1 \text { км от берега }\end{array}$ & 17 & 15 & 3 & 0 & 0 & 0 & 0 & 0 & 6 \\
\hline Тихоокеанское & 17 & 50 & 30 & $1+8^{*}$ & 0 & 10 & 6 & $1 *$ & 18 \\
\hline Охотоморское & 25 & 34 & 13 & 9 & 1 & 1 & 2 & 9 & 32 \\
\hline Всего & 42 & 84 & 43 & $10+8^{*}$ & 1 & $11^{*}$ & $8 *$ & $9+1 *$ & 50 \\
\hline
\end{tabular}

Примечание: *найденные с помощью программы Google Earth

Рассмотрим водопады, встречающиеся в прибрежной зоне Курильских островов с точки зрения туризма. Важное значение в настоящее время имеет экологический туризм. Он предусматривает такие моменты как:

- Социальная значимость его значительно больше, чем экономическая;

- Повышение уровня экономической активности и стабилизации экономики региона при минимальных затратах;

- Экотуризм может стать альтернативой лесозаготовкам и браконьерству; 
- Дополнительные средства, помимо основных доходов от туризма (входная плата, различные взносы за туристские услуги, продажа сувениров, путеводителей);

- Правильное планирование туристских нагрузок и распределение туристских потоков.

Исходя из особенностей расположения, климатических условий, транспортной доступности, количества достопримечательностей каждого острова, можно составить туристские маршруты выходного дня, пешеходные и морские.

Кунашир - третий по площади после Итурупа и Парамушира и самый южный остров Большой Курильской гряды. Длина острова -

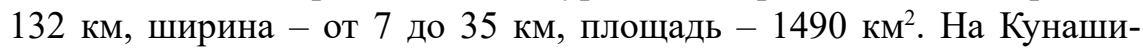
ре (и Шикотане) самый мягкий климат из всех островов Курильской гряды и 5 жилых населенных пунктов, главным из которых является Южно-Курильск, есть аэропорт и морское сообщение с Сахалином.

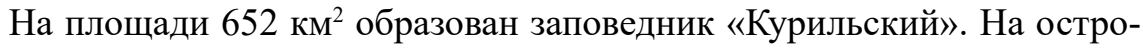
ве 4 действующих вулкана (Тятя, Руруй, Менделеева и Головнина), горячие источники Докторские и Горячий Пляж, мыс Столбчатый, а также 52 водопада. Из них 19 водопадов расположены на реках и ручьях с тихоокеанской стороны Кунашира, 21 - с охотоморской стороны северной части острова. 25 водопадов - прибрежных, 17 - на расстоянии до 1 км от берега.

Наиболее богато водопадами северное и юго-восточное побережье Кунашира. Но северное побережье острова изобилует скалами-непропусками. На участке в 40 км от мыса Прасолова почти до самого перешейка Кругловского зарегистрировано 16 водопадов. При планировке маршрутов к этим берегам нужно быть готовыми к прохождению скальных прижимов у самого моря с подъемом на утесы, либо по узкой полосе берега в отлив. На этом участке у мыса Белый Утес находятся Нескученские термальные источники с температурой воды +50 гр. Достоин внимания 15-метровый водопад у мыса Нелюдимый, распадающийся на множество струй. Очень красив водопад Птичий в 50 м выше устья одноименной реки, поток воды шумный и мощный, над водопадом можно увидеть радугу [4].

От Южно-Курильска можно совершить несколько более простых экскурсий. Конечно, не стоит пренебрегать возможностью побывать на мысе Столбчатом - уникальнейшем образовании из базальтовых лав, потрескавшихся в форме пяти- и шестигранников и поднявшихся 
со дна моря 5-6 млн лет назад. Но путь к мысу не пересекает «водопадных» маршрутов. Знакомство с «летящей водой» южного Кунашира можно начать с горячих Докторских источников на восточном склоне вулкана Менделеева. В 4 км к югу от Южно-Курильска по реке Лесной нужно подняться до ручья Кислый. Небольшой водопад с температурой воды $40^{\circ} \mathrm{C}$ приятен и полезен.

12 водопадов расположено на ручьях тихоокеанского побережья между мысом Горячий и поселком Головнино. На Горячем пляже струйки горячего пара вырываются прямо из песка. Очень интересен первый от устья 4-метровый водопад, расположенный на ручье Четверикова. Водопад находится в каньоне, оба борта которого своей необычной конфигурацией напоминают профили мужчины и женщины, смотрящих друг на друга [3]. Высокое и обрывистое тихоокеанское побережье сложено пемзовыми туфами серого цвета и отшлифовано волнами. С таких пемзовых клифов, аккуратно выточив себе желобок, вертикальными струями падают 2 водопада по 40 м высотой (ручьи Виктория и Пьяный), через 4 и 2 км от них встречаются 35- и 25 -метровый водопады. Водопад Виктория отмечен на топокарте как 60-метровый, но хорошо просматриваются только 40 м высоты, верхняя часть скрыта растительностью, к тому же на пемзовой поверхности очень высокая скорость эрозии. Проход вдоль берега возможен по узкой полосе пляжа [4] (рис. 1).

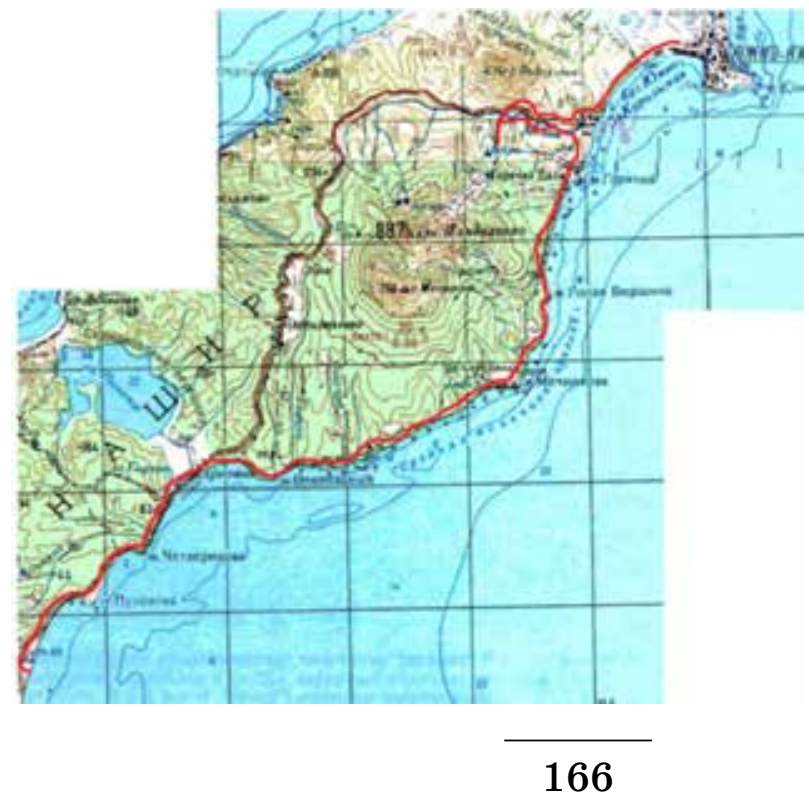

Рис. 1. Схема маршрута по юго-западному побережью о. Кунашир [8] 
Остров Итуруп самый большой в архипелаге, длина его 203 км,

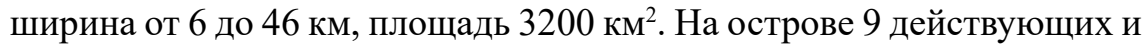
7 потухших вулканов, более 30 озер, реки горные, короткие, имеются выходы термальных вод на склоне вулкана Баранского, Рейдовские и др., пемзовые Белые скалы и Черные базальтовые экструзии, затопленная кальдера Львиная Пасть и многие другие достопримечательности. Южную часть острова (юго-западнее линии «река Черная гора Буревестник - река Отливная») занимает заказник «Островной». Итуруп отличается наибольшим количеством водопадов из всех островов Сахалинской области, их здесь 213. В отличие от других островов Курильской гряды, большинство водопадов находится во внутренних районах острова. Прибрежных водопадов насчитывается 84, тогда как внутриостровных 129 [3]. Некоторые интересные объекты водопадного мира, расположенные на некотором отдалении от береговой линии, желательно включать в туристские маршруты, приуроченные к побережью. Например, Лимонитовый каскад на полуострове Чирип, расположенный в 3 км от устья р. Северный Чирип. По пути к нему также можно увидеть 18-метровый водопад в 1,3 км от устья. Также очень красив водопад Дуговой с минерализованной кислой водой на Тихоокеанском побережье, который прекрасно дополнит список достопримечательностей участка берега между мысами Исоя и Рогатый [2].

Наибольшее количество водопадов наблюдается на северо-восточном побережье острова, в центральной его части на обоих берегах. Тихоокеанское побережье в северной части представляет собой труднопроходимые скалы-прижимы. Водопады здесь от 20 до 60 метров высотой, но обход их по крутым берегам, местами покрытым зарослями курильского бамбука высотой до 3,5 метров. На охотоморской же стороне от перешейка Осеннего до мыса Одесский водопадами обрываются в море 15 речек и ручьев, которые сбегают по западному склону хребта Богатырь, и в том числе, самого высокого, но потухшего вулкана Стокап (1634 м). Этот маршрут удобно проходить морем на катере из бухты Осенней, до которой можно доехать на автомобиле из города Курильска [2]. Высадка на берег возможна у реки Черная, пешая прогулка по берегу, к ближайшим водопадам. Очень красивы водопады в 2 и 3 км вдоль побережья к югу от реки Горная: один из них, 7 м высотой, падает прозрачным веером на водную гладь, другой, 10-метровый - на каменистую литораль. Водопад 
в устье ручья Бамбуковый падает ступенями прямо в море, создавая яркий контраст с черными скалами. Остановка возможна в заливе Одесский с видом на один из самых красивых вулканов мира - Адсонопури. Участок берега от бухты Осенняя до залива Одесский, «несмотря на наличие «непропусков», проходим ногами» (А. Клитин, с.119) [3].

Уруп - четвертый по величине остров Курильской гряды, длина острова - 120 км, максимальная ширина -20 км, площадь -1450 км² $^{2}$ Из 25 вулканов на острове только 3 действующие - Трезубец, Берга и Колокол. Берега Урупа преимущественно абразионные, скалистые, литораль сложена галькой и валунами, многочисленны труднопроходимые участки в виде выступающих в море мысов и вулканических даек, пересекающих литораль. Реки имеют V-образный продольный, невыработанный ступенчатый профиль, большую глубину и слабое развитие террас. Есть лагунное озеро Токотан и лавоподпрудное Высокое. На мысе Ключевой расположены горячие источники кислой слабоминерализованной воды с температурой $+52^{\circ} \mathrm{C}$, они расположены на 20 м над уровнем моря и падают горячим белым водопадом с 17-метровой высоты. Красивы водопады юго-западной части Урупа: Така (60 м) - вертикальный ровный поток, на мысе Севрюга (15 м) - вырывается из узкой долины и разбивается о морскую гладь, этот водопад труднопроходим по мысу, и на мысе Несчастья (50 м) широкий и мощный поток падает по наклонным (около 50 градусов) скалам. Семь водопадов находятся на реках и ручьях, берущих начало на склоне вулкана Берга. Нужно упомянуть о двух водопадах, не береговых, но находящихся на расстоянии 1-2 км от берега Охотского моря на северо-западном склоне вулкана Берга в центральной части острова. Две горные речки - Марья и Дарья - протекают по глубоким ущельям и срываются вниз 150-метровыми потоками. По свидетельству исследователя Курильских островов К.Н. Рудича, у основания они образуют Марьинские и Дарьинские термальные источники и Лимонитовый каскад (вынося из горных пород железо). Факт наличия этих водопадов подтвердил в 2012 году Д. Веселов в своих путевых заметках «Сердце Урупа». Эти водопады могут оказаться самыми высокими в Сахалинской области, но они не обозначены на картах. На юго-восточном побережье расположено 19 водопадов, начиная от мыса Кузиноты до Сквознякового перешейка. Среди них красивый 10-метровый водопад, спадающий по 70-градусному уступу, располо- 
Рис. 2. Маршрут по юго-восточному побережью о. Уруп

[8]

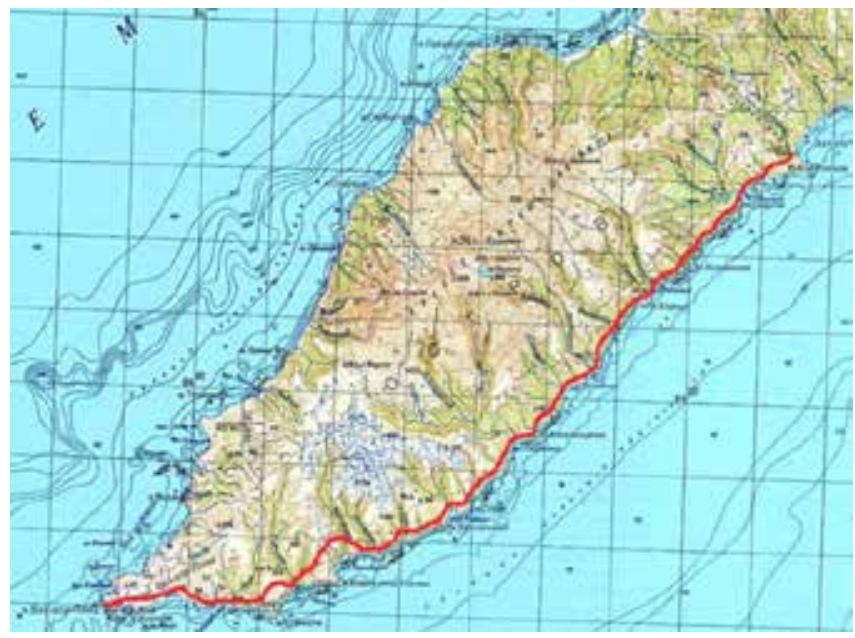

женный между бухтой Сокол и рекой Голубичная. У мыса Борода находится красивый 25-метровый двухступенчатый водопад (6 и 19 м). Северо-восточная часть острова отмечена 19-ю водопадами, но о них информации мало [3] (рис. 2).

Остров Онекотан - длина его 42 км, ширина достигает 17 км, площадь 435 км². Северная часть острова представлена вулканической кальдерой, в центре которой образовался новый вулканический купол - Немо (1019 м). С северной стороны от вершины в понижении образовалось озеро Черное. Край разрушенной кальдеры выровнялся до практически ровной поверхности на 400 м над уровнем моря. Центральная часть представляет собой равнинный берег, возвышенности плавно спускаются к морю, переходят в низменный песчаный берег. Течение рек спокойное, на тихоокеанской стороне встречаются небольшие меандры. Южная часть острова представлена разрушенной вулканической кальдерой Тао-Русыр, внутри которой образовалось озеро Кольцевое глубиной 260 м. Озеро не имеет стока и в него не впадает ни один ручеек. В центре озера возвышается конус действующего вулкана Креницына, высотой 1324 м. Остров внутри острова - географический феномен. Попасть на Онекотан возможно только на судне, с соседнего острова Парамушир, по договоренности. До Северо-Курильска летают вертолеты из Петропавловска-Камчатского, бывает, что с задержкой до 2 недель изза плохой погоды. Высадка на берег Онекотана происходит обычно 
на рейде у брошенной погранзаставы Шестаково на охотоморском берегу, затем на лодке к берегу. Большая часть из 10 водопадов Онекотана находятся вблизи заставы, на западном склоне горы Шестакова (707 м). Водопад реки Мойка впадает в Охотское море мощным 20 -метровым потоком. На тихоокеанской стороне на снимках Google Earth просматривается 8-метровый водопад у мыса Ягодный, но информация нуждается в подтверждении. Интересно увидеть озеро Кольцевое, поднявшись на борт кальдеры. Известны случаи, когда туристы несли с собой резиновую лодку, чтобы поплавать по озеру и затем подняться на вершину вулкана Креницына [9]. Остров Онекотан ждет своих исследователей.

Остров Парамушир - протяженность его 100 км, ширина 20-

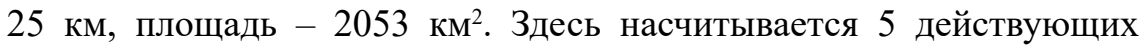
(Эбеко, Чикурачки, Татаринова, Карпинского и Фусса) и 15 потухших вулканов. Протяженность абразионных и абразионно-денудационных берегов на острове около 225 км. Реки короткие, но из-за активного таяния снега в течение всего безморозного периода полноводные и порой труднопроходимые. Природа Парамушира отличается большей суровостью, из-за холодного и короткого лета. Здесь не растет бамбук, кедрового стланика мало и до высоты 600 м его заменяет ольховый [3]. На острове сохранилось множество японских военных сооружений времен Второй Мировой войны, а также брошенные советские поселения, разрушенные сокрушительным цунами 1952 г. Попасть на Парамушир можно только из Петропавловска-Камчатского вертолетом до Северо-Курильска. В ходе путешествия Андрея Клитина в 2005 году по острову Парамушир, было уточнено местоположение и высота 59 водопадов. Береговых из них 50, включая 6 на отдалении от берега до 1 км. Наибольшее количество водопадов наблюдается на тихоокеанском побережье острова, на участке от реки Прозрачная до мыса Крузенштерна, здесь их 14 . Но неподготовленному туристу здесь придется сложно, так как встречаются скалы-непропуски, обрывающиеся прямо в океан, которые придется проходить либо по крутым подъемам и густым зарослям, либо использовать навыки скалолазания. Все водопады этого участка падают на океанскую литораль. Очень эффектный водопад Ближний - 30-метровый вертикальный двухступенчатый поток [5]. Этот отрезок пути от Северо-Курильска до мыса Хмурый, затем подъем на все действующие вулканы с переходом на охотоморскую сторону и возвращением в Северо-Курильск 
прошла группа Сергея Ляховца в 2012 г. Поход продолжался 46 дней и составил V категорию сложности [6].

Более простой по прохождению, но не менее насыщенный водопадами участок - юго-запад побережья от мыса Капустный до устья реки Стрелы. Водопады относятся к абразионно-тектоническому типу. Берег здесь пологий, но в самом начале есть скала-непропуск, которая обходится вброд в отлив. Далее на 15-км участке насчитывается 14 водопадов от 10 до 18 м высотой. Полноводный и изящный Савочкин водопад спадает в прибрежные заросли. Алёшин 10-метровый водопад веером спускается со скальной поверхности с 50-градусным уклоном. Заброска на этот отрезок побережья в силу его отдаленности от Северо-Курильска возможна морем, но «На острове, где нет дорог, надеяться можно только на собственные ноги» (А.К. Клитин, c. 441) [5].

Научный руководитель: д.г.н., профессор ДВФУ Бровко П.Ф.

\section{Литература}

1. Бровко П.Ф. Водопады: стихия и поэзия. Владивосток: Изд-во ДВФУ, 2018. $212 \mathrm{c}$.

2. Васина М.В. Водопады о. Итуруп как рекреационный ресурс // Геосистемы Северо-Восточной Азии: особенности их пространственно-временных структур, районирование территории и акватории. Владивосток: ФГБУН ТИГ ДВО РАН, 2019. C. $157-164$.

3. Клитин А. К., Бровко П. Ф., Горбунов А. О. Водопады. Южно-Сахалинск: ГБУК «Сахалинский обл. краеведческий музей», 2013. 167 с.

4. Клитин А.К. Незнакомый Кунашир [Электронный ресурс] // Вестник Сахалинского музея. 2002. № 9. С. 401-419. - Режим доступа: http://sakhalinmuseum.ru/ ufile/522_401.pdf (дата обращения: 11.07.2019).

5. Клитин А.К. Остров, где нет дорог [Электронный ресурс] // Вестник Сахалинского музея. 2004. № 12. С. 437-461. - Режим доступа: http://sakhalinmuseum.ru/ ufile/359_437.pdf (дата обращения: 11.07.2019).

6. Ляховец С. Отчет о пешеходном туристском походе V категории сложности по острову Парамушир (Курильские острова) и полуострову Камчатка. 2012 [Электронный ресурс] // Горы мира. Камчатка. Mauntain.ru. - Режим доступа: http://www. mountain.ru/article/article_displayl.php?article_id=6719 (дата обращения: 09.07.2019).

7. Петрова О.О., Петрушина М.Н., Самойлова Г.С. Водопад [Электронный ресурс] // Научно-популярная энциклопедия «Вода России». - Режим доступа: http:// water-rf.ru/Глоссарий/1851/Водопад (дата обращения: 12.07.2019).

8. Топокарты Генштаб [Электронный ресурс] // Карты всего мира. - Режим доступа: http://loadmap.net/ru (дата обращения: 14.07.2019).

9. Шкрябин В. Остров Онекотан - вулкан Креницына [Электронный ресурс] // Green Tour - Спортивно-туристический клуб. - Режим доступа: http://turizm.primkray. $\mathrm{ru} /$ trek/ostrov-onekotan-vulkan-krenicina (дата обращения: 12.07.2019). 


\section{References}

1. Brovko P.F. Vodopady: stihiya I poeziya [Waterfalls: nature and poetry]. Vladivostok, DVFU Publ., 2018. 212 p.

2. Vasina M.V. [Waterfalls Iturup Island as a Recreational Resource]. Materialy Vserossiiskoy konferencii "Geosystemy Severo-Vostochnoy Azii: osobennosti ih prostranstvenno-vremennyh structur, rayonirovanie territorii $i$ aquatorii» [Collection of scientific articles «Geosystems of North-East Asia: the peculiarities of their spatial-temporal structures, zoning of land and waters»]. Vladivostok, 2019, pp. 157-164.

3. Klitin A.K., Brovko P.F., Gorbunov A.O. Vodopady [Waterfalls]. Yuzhno-Sakhalinsk, 2013. $168 \mathrm{p}$.

4. Klitin A.K. Neznakomyi Kunashir [Unfamiliar Kunashir]. Vestnik Sakhalinskogo Museya -News of the Sakhalin Museum, 2002, no. 9, pp. 401-419. Available at: http:// sakhalinmuseum.ru/ufile/522_401.pdf (accessed 11.07.2019).

5. Klitin A.K. Ostrov, gde net dorog [Island, where there are no roads]. Vestnik Sakhalinskogo Museya - News of the Sakhalin Museum, 2004, no. 12, pp. 437-461. Available at: http://sakhalinmuseum.ru/ufile/359_437.pdf (accessed 11.07.2019).

6. Lyahovets S. Otchet o peshehodnom pohode V kategorii slozhnosti po ostrovu Paramushir (Kuril skie ostrova) i poluostrovu Kamchatka [Report about the Hiking tour of the V category of complexity on the skeleton of Paramushir (Kuril Islands) and the Kamchatka Peninsula], 2012. Available at: http://www.mountain.ru/article/article_display1. php?article_id=6719 (accessed 09.07.2019).

7. Petrova O.O., Petrushina M.N., Samoylova G.S. Vodopad [Waterfall]. Available at: http://water-rf.ru/Глоссарий/1851/Водопад (accessed 12.07.2019).

8. Topografic maps General staff. Available at: http://loadmap.net/ru (accessed 14.07.2019).

9. Shkryabin V. Ostrov Onecotan - Vulcan Krenitsina [The Island of Onecotan - the volcano of Krenitsin]. Available at: http://turizm.primkray.ru/trek/ostrov-onekotan-vulkan-krenicina (accessed 12.07.2019). 